\title{
Clinical application of ghrelin administration for gastric cancer patients undergoing gastrectomy
}

\author{
Shuji Takiguchi $\cdot$ Akihiro Takata $\cdot$ Kohei Murakami \\ Yasuhiro Miyazaki · Yoshitomo Yanagimoto · Yukinori Kurokawa • \\ Tsuyoshi Takahashi $\cdot$ Masaki Mori $\cdot$ Yuichiro Doki
}

Received: 25 March 2013/Accepted: 30 August 2013/Published online: 20 September 2013

(c) The International Gastric Cancer Association and The Japanese Gastric Cancer Association 2013

\begin{abstract}
Loss of body weight is a common (and the most serious) sequela after gastrectomy. It impairs quality of life, increases various diseases including infection, and may affect long-term survival. Ghrelin, an intrinsic ligand of the growth hormone secretagogue receptor, was discovered in the stomach in 1999. In addition to growth hormone secretion, ghrelin has pleiotropic functions including appetite stimulation, increasing bowel movement and absorption, and anti-inflammatory reactions. In consequence, ghrelin comprehensively leads positive energy balance and weight gain. The fundic gland of the stomach produces the majority of ghrelin, and plasma ghrelin declines to $10-30 \%$ of the preoperative level after total gastrectomy and 50-70\% after distal gastrectomy. Although plasma ghrelin is never restored after total gastrectomy, it gradually recovers to the preoperative level within a few years after distal gastrectomy. Chronic gastritis due to Helicobacter pylori infection and vagotomy are additional factors that perturb the ghrelin secretion of gastric cancer patients after gastrectomy. A randomized clinical trial that revealed that recombinant ghrelin administration successfully increased both food intake and appetite, and ameliorated weight loss after total gastrectomy. Ghrelin administration could thus be a promising strategy to transiently improve the nutritional status of patients who who have undergone gastrectomy, but its effect in the long term remains unclear. Further studies are
\end{abstract}

S. Takiguchi $(\bowtie) \cdot$ A. Takata $\cdot$ K. Murakami · Y. Miyazaki ·

Y. Yanagimoto · Y. Kurokawa - T. Takahashi · M. Mori ·

Y. Doki

Division of Gastroenterological Surgery, Department of Surgery,

Graduate School of Medicine, Osaka University, 2-2 E2

Yamadaoka, Suita, Osaka 565-0871, Japan

e-mail: stakiguchi@gesurg.med.osaka-u.ac.jp warranted to elucidate the mechanism of ghrelin and to create and evaluate the analogs that could be administered orally or subcutaneously.

Keywords Ghrelin · Gastrectomy · Gastric cancer · Weight loss

\section{Introduction}

Loss of body weight is a common, serious outcome in patients with gastric cancer who have undergone gastrectomy. It correlates well with a decline in postoperative quality of life and is the most reliable indicator of malnutrition, which impairs immune function, infection susceptibility, and survival [1-3]. Although various mechanisms have been considered, such as the perturbation of absorption due to reduced pancreatic excretion [4, 5], a decrease in the gastric acid level [6], reflux esophagitis [7], intestinal floral alteration [8], and increased peristalsis and diarrhea [9], reduced food intake [10, 11] is the most conceivable explanation for weight loss after gastrectomy. To combat loss of appetite, surgeons dealing with gastric cancers have tried to increase food intake by producing a gastric substitute, such as a jejunal pouch, with limited success [12]. However, we frequently observe that patients do not exhibit significant weight loss after total gastrectomy when they resort to small but frequent meals. Another study indicated that the majority of patients with total gastrectomy were able to eat as much food as healthy subjects under a regulated program [13].

Taken together, we can conclude that (1) patients who have undergone gastrectomy have the ability to maintain body weight when food intake is adequately performed; (2) only loss of storage volume cannot account for reduced 
food intake after gastrectomy; (3) there is a relatively large change in eating behavior after gastrectomy that is controlled by an unknown mechanism. In this review, we discuss ghrelin and research about its clinical applications.

\section{The discovery of ghrelin and its features}

Ghrelin is a peptide hormone that was discovered in 1999 as an endogenous ligand for the growth hormone (GH)-secretagogue receptor (GHS-R). The 28-amino-acid ghrelin peptide is the endogenous ligand for GHS-R1a, which stimulates GH release from the pituitary gland [14]. X/A-like cells of the oxyntic glands in the stomach produce the majority of ghrelin, and smaller amounts are secreted by other organs, such as the intestine, pancreas, kidney, and hypothalamus $[15,16]$. Ghrelin has several physiological functions in addition to the secretion of $\mathrm{GH}$, including the promotion of the appetite signal that antagonizes leptin in the hypothalamus [17], stimulation of gastrointestinal activity (e.g., peristalsis, gastric acid secretion, and pancreatic excretion through the vagal nerves) [18], and regulation of fat metabolism [19] (Table 1). Ghrelin also mitigates proinflammatory cytokine production and attenuates the stress signal [20]. Ghrelin exists as two major molecular forms: acyl ghrelin and des-acyl ghrelin. Ghrelin is octanoylated at Ser3, an unusual post-translational modification that is catalyzed by the enzyme ghrelin O-acyltransferase (GOAT) $[21,22]$. Des-acyl ghrelin, which lacks the Ser3 residue octanoylation, is unable to release $\mathrm{GH}$ or bind to the classic GHS-R1a receptor [23]. These characteristics indicate that octanoic acid plays an important role in physiological activity via GHS-R1a, and des-acyl ghrelin has been considered an inactive form of ghrelin.
Ghrelin peptide is the only gastrointestinal hormone known to stimulate appetite. A randomized double-blind study of healthy volunteers demonstrated that ghrelin enhances appetite and increases food intake [24, 25]. Several clinical trials of patients with heart failure [26], pulmonary disease [27], cancer cachexia [28], or undergoing chemotherapy [29] concluded that ghrelin successfully improved their diseases along with increased oral food intake and body weight. In the field of surgical treatment for obesity, reduced ghrelin levels after sleeve gastrectomy are associated with successful weight loss and appetite suppression [30]. Taken together, the discovery of ghrelin allows the proposal of a new concept, body weight regulation by the stomach, which can be applied to various diseases with malnutrition.

\section{Gastrectomy and ghrelin secretion}

Fundic glands in the stomach produce the majority of ghrelin. Patients with resected gastric cancer experience low plasma ghrelin concentrations. Table 2 lists studies of the change in ghrelin concentration after gastrectomies [3137]. In total gastrectomy patients, ghrelin concentrations were immediately reduced to $12-29 \%$ of the preoperative concentration. In contrast, ghrelin concentrations decreased to $39-71 \%$ of the preoperative concentration immediately after distal gastrectomy. These reductions in ghrelin concentration are a direct result of the fact that most ghrelin is produced by A-like cells in the fundic gland of the stomach. In fact, sleeve gastrectomy for bariatric surgery immediately results in a $67 \%$ reduction in the concentration of ghrelin [38]. H. pylori infection also markedly reduces ghrelin-producing cells and plasma ghrelin.

Table 1 Physiological functions of ghrelin

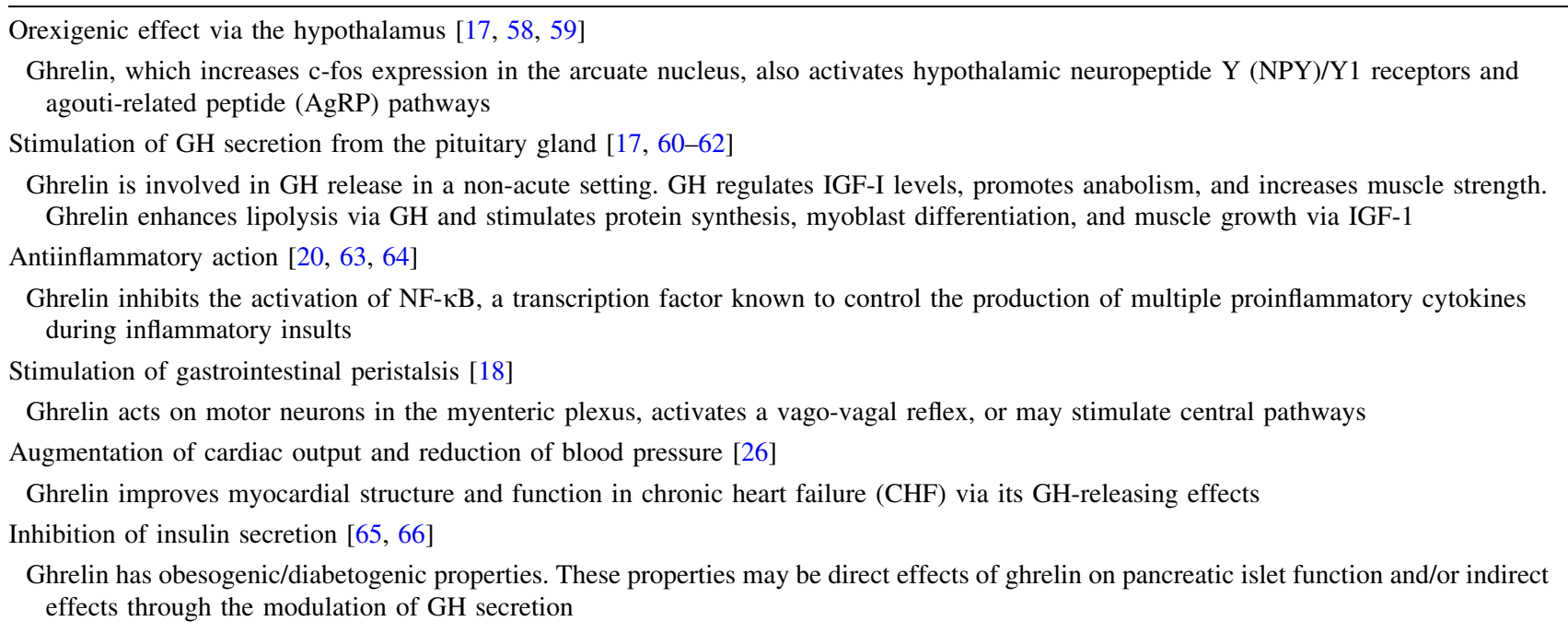


Table 2 Representative reports of changes in ghrelin concentration in patients who have undergone gastrectomy

\begin{tabular}{|c|c|c|c|c|c|}
\hline \multirow[t]{2}{*}{ References } & \multirow[t]{2}{*}{ Procedure } & \multirow[t]{2}{*}{ Number of cases } & \multirow[t]{2}{*}{ Preoperative ghrelin level } & \multicolumn{2}{|c|}{$\begin{array}{l}\text { \% Postoperative decline of ghrelin } \\
\text { concentration from baseline }\end{array}$} \\
\hline & & & & Short term $(\%)$ & Long term $(\%)$ \\
\hline Jeon et al. [32] & DG & 24 & Active $276 \mathrm{pg} / \mathrm{ml}\left(82.7 \mathrm{fmol} / \mathrm{ml}^{\mathrm{a}}\right)$ & $\begin{array}{l}\text { Day } 151 \\
\text { Day } 788\end{array}$ & \\
\hline Takachi et al. [35] & DG & 38 & Total $95 \mathrm{fmol} / \mathrm{ml}$ & Day 339 & 3 years 77 \\
\hline Wang et al. [36] & DG (B-I) & 23 & Active $468 \mathrm{pg} / \mathrm{ml}\left(138.8 \mathrm{fmol} / \mathrm{ml}^{\mathrm{a}}\right)$ & $\begin{array}{l}\text { Day } 137 \\
\text { Day } 751\end{array}$ & 1 year 93 \\
\hline Wang et al. [36] & DG (B-II) & 19 & Active $460 \mathrm{pg} / \mathrm{ml}\left(136.5 \mathrm{fmol} / \mathrm{ml}^{\mathrm{a}}\right)$ & $\begin{array}{l}\text { Day } 136 \\
\text { Day } 751\end{array}$ & 1 year 82 \\
\hline Kim et al. [34] & DG & 45 & Total $310 \mathrm{pg} / \mathrm{ml}\left(92 \mathrm{fmol} / \mathrm{ml}^{\mathrm{a}}\right)$ & Day 271 & 3 months 81 \\
\hline Kamiji et al. [33] & DG & 14 & Active $993 \mathrm{pg} / \mathrm{ml}\left(294.2 \mathrm{fmol} / \mathrm{ml}^{\mathrm{a}}\right)$ & - & 6 years 77 \\
\hline Jeon et al. [31] & DG & 18 & Active $113 \mathrm{pg} / \mathrm{ml}\left(33.5 \mathrm{fmol} / \mathrm{ml}^{\mathrm{a}}\right)$ & $\begin{array}{l}\text { Day } 150 \\
\text { Day } 785\end{array}$ & 1 year 57 \\
\hline Zub-Pokrowieckae al. [37] & DG & 10 & Active $293 \mathrm{pg} / \mathrm{ml}\left(86.9 \mathrm{fmol} / \mathrm{ml}^{\mathrm{a}}\right)$ & - & $4-5$ years 82 \\
\hline Jeon et al. [31] & TG & 12 & Active $390 \mathrm{pg} / \mathrm{ml}\left(115.7 \mathrm{fmol} / \mathrm{ml}^{\mathrm{a}}\right)$ & $\begin{array}{ll}\text { Day } 1 & 29 \\
\text { Day } 7 & 30\end{array}$ & - \\
\hline Takachi et al. [35] & TG & 26 & Total $95 \mathrm{fmol} / \mathrm{ml}$ & Day 312 & 3 years 20 \\
\hline Kamiji et al. [33] & TG & 7 & Active 993 pg/ml $\left(294\right.$ fmol/ml $\left.{ }^{\mathrm{a}}\right)$ & - & $3-5$ years 51 \\
\hline Zub-Pokrowiecka et al. [37] & TG & 10 & Active $293 \mathrm{pg} / \mathrm{ml}\left(86.9 \mathrm{fmol} / \mathrm{ml}^{\mathrm{a}}\right)$ & - & $4-5$ years 46 \\
\hline Jeon et al. [32] & PG & 4 & Active $427 \mathrm{pg} / \mathrm{ml}\left(126.7 \mathrm{fmol} / \mathrm{ml}^{\mathrm{a}}\right)$ & $\begin{array}{l}\text { Day } 125 \\
\text { Day } 748\end{array}$ & - \\
\hline
\end{tabular}

$T G$ total gastrectomy, $D G$ distal gastrectomy, $P G$ proximal gastrectomy, $B$ - $I$ Billroth-I reconstruction, $B$ - $I I$ Billroth-II reconstruction

${ }^{a} \mathrm{x} \mathrm{pg} / \mathrm{l}$ was converted to $\mathrm{x} / 3.3709 \mathrm{fmol} / \mathrm{ml}$

Generally, patients with gastric cancer and atrophic gastritis have a low basal level of ghrelin. Therefore, the degree of decline caused by gastrectomy can be considered low. Ghrelin concentrations recover relatively soon after surgery; many studies have shown that at 7 days after surgery, the ghrelin concentrations of patients with distal gastrectomy were $51-88 \%$ of preoperative levels. In the long term, postoperative plasma ghrelin levels sometimes approach preoperative levels in patients who have undergone distal gastrectomy. It has been reported that the number of ghrelin-producing cells does not increase after gastrectomy [39]. Persistent low body weight after gastrectomy might stimulate ghrelin secretion from individual ghrelin-producing cells in a negative feedback manner. In contrast, the plasma ghrelin concentrations of patients who have undergone total gastrectomy do not rebound to normal levels if the patients suffer from continuous malnutrition [35]. Although ghrelin is produced by organs other than the stomach, those sources cannot sufficiently compensate for the disappearance of ghrelin-producing cells in the stomach.

\section{Vagotomy and ghrelin response}

Both anterior and posterior vagal trunks were usually resected during gastrectomy for gastric cancer, especially in order to complete D2 lymph node dissection. Therefore, we should consider the influence of truncal vagotomy on ghrelin signals in both afferent and efferent pathways. In the rodent, vagotomy alone has led to the significant reduction of the baseline of fasting plasma ghrelin [40]. After radical esophagectomy for esophageal cancers (which includes truncal vagotomy and reconstruction of the whole gastric tube), ghrelin secretion in human patients was reduced by one-half compared to preoperative levels and gradually recovered within a few years [41, 42].

Vagotomy also perturbs the normal ghrelin secretion response (i.e., significant decline immediately after oral food intake). Pekic et al. [43] performed an oral glucose tolerance test (OGTT) in gastrectomized/vagotomized patients and BMI-matched control patients. Plasma ghrelin levels decreased significantly during the OGTT in control subjects, while no reduction was detected in gastrectomized-vagotomized patients. We frequently employ distal gastrectomy, which preserves the celiac branch of the vagal nerve. The downregulation of plasma ghrelin by food intake was significantly greater in patients with vagal nerve preservation than in patients with complete vagotomy (unpublished observation).

With respect to the efferent pathway, there is a report that the administration of exogenous ghrelin stimulated GH 
secretion in vagotomized patients as much as in normal subjects [44]. Increases in appetite and amount of food intake after ghrelin administration are reportedly less significant in vagotomized patients than in control patients [45]. However, other studies in rats reported that ghrelin successfully stimulated food intake after vagotomy when administered intraperitoneally [46]. Moreover, in our previous study, intravenous administration of exogenous ghrelin successfully stimulated food intake and appetite immediately after total gastrectomy and esophagectomy [47, 48]. Our findings suggested that the administered ghrelin crossed the blood-brain barrier to the central nervous system, likely increasing the appetite signal through both the vagal pathway and the circulatory system.

As a whole, vagotomy definitely damages the normal control of ghrelin secretion. However, the relationship between ghrelin and vagotomy remains poorly defined in the output system of endogenous and exogenous ghrelin. Therefore, we cannot draw conclusions about the influence of vagotomy on the biological effects of ghrelin, although $\mathrm{GH}$ secretion and appetite stimulation may be differently involved with the vagal nerve. Further observation and experiments are required to clarify this issue.

\section{Effects of ghrelin administration after total gastrectomy}

Because the anabolic effect of ghrelin is apparent, the possible clinical applications of ghrelin in the context of various cachexic states (e.g., anorexia nervosa, heart failure, chronic obstructive pulmonary disease, and the terminal stage of unresectable cancers) should be considered. These studies have demonstrated increases of oral food intake and body weight in both humans and rats. The two species do differ with regard to body composition. For example, ghrelin administration tended to increase fat volume in the rat, while muscle weight and muscle power have been increased more than fat volume in humans.

There are two large differences in the rationale of ghrelin administration with respect to the cachexic states listed above and the post-gastrectomy state. By various means, cachexia has consistently exhibited high plasma ghrelin concentrations combined with weight loss as the result of negative feedback; the effect of exogenous ghrelin may be restricted if the ghrelin signals are already saturated by endogenous ghrelin. In contrast, the post-gastrectomy state is associated with low plasma ghrelin combined with significant weight loss. Therefore, in the latter context it appears reasonable to administer exogenous ghrelin to compensate for reduced endogenous ghrelin. In this respect, we can expect more significant ghrelin effects in gastrectomy patients than in cachexic patients. Another concern is the influence of vagotomy, which, as described in the previous section, might minimize the effect of ghrelin in gastrectomy patients.

There is a randomized, phase II study [47] in which 21 patients undergoing total gastrectomy were assigned to groups receiving ghrelin $(n=11)$ or a placebo $(n=10)$. In the 10 days after starting oral food intake (postoperative days 5-7), an intravenous drip infusion of synthetic human ghrelin $(3 \mu \mathrm{g} / \mathrm{kg})$ or placebo (pure saline) was administered twice daily (before breakfast and before dinner). The mean intake over the 10-day period represented a $32.7 \%$ increase in the ghrelin group compared with the placebo group (13.8 vs. $10.4 \mathrm{kcal} / \mathrm{kg} / \mathrm{day})$. At the end of the study period, weight loss was $3.7 \%$ for the placebo group compared with $1.4 \%$ for the ghrelin group. They used dual-energy X-ray absorptiometry to measure body composition. Fat mass, lean body mass and basal metabolic rate decreased significantly in the placebo group; however, the reductions in lean body mass and basal metabolic rate were not significant in the ghrelin group, although the reduction of fat mass was significant. Therefore, exogenous ghrelin lessened weight loss, especially the loss of lean body mass. There were no significant side effects; however, one patient experienced grade 1 diaphoresis. Several months after the trial, there was no between-group difference in weight or appetite. The most critical drawback is that they are currently only able to administer ghrelin intravenously. For long-term administration, another delivery system (e.g., subcutaneous injection or inhalation) should be developed [49]. Oral ghrelin analog, which is already in clinical trials, is a possible ghrelin substitute.

As ghrelin is also a potent $\mathrm{GH}$ secretagogue, there are concerns about GH-mediated stimulation of tumor growth, especially regarding treatment of cancer patients. In vitro studies suggest that ghrelin may enhance the proliferation of prostate [50] and pancreatic [51] cancer cells, but not of a lung cancer cell line, where it induced dose-dependent inhibition of cell proliferation and increased apoptosis [52]. Some tumors from archival samples express ghrelin [53], whereas others (gastric cancer and esophageal cancer) do not [54]. According to a review that analyzed ghrelin administration studies, there was no report of anyone suffering from new cancer as an adverse event among 1,850 participants who were registered to 121 studies. [55-57].

\section{Conclusion}

Although our prospective randomized study had a limited number of patients and short-term observation periods, it revealed the beneficial effects of the administration of exogenous ghrelin on body weight and oral intake after total gastrectomy. Although there are issues that must be resolved before clinical application, including elucidation of the 
duration of administration and adequate assessment of clinical benefits, surgeons dealing with gastric cancers should be encouraged by the availability of ghrelin. Although decline of ghrelin is certain to play a major role in appetite loss after gastrectomy, it cannot account for all causes that lead to body weight loss. Some patients continue to weigh less even after the amount of food intake has recovered, possibly because of vagotomy, defective fat absorption due to pancreatic insufficiency, bacterial overgrowth, and shortened small bowel transit time [13]. Although surgery is essentially non-physiological and highly invasive, it remains the most reliable therapeutic option to cure cancer. Therefore, it is our obligation to invent new procedures to minimize postoperative side effects.

\section{References}

1. Demas GE, Drazen DL, Nelson RJ. Reductions in total body fat decrease humoral immunity. Proc Biol Sci. 2003;270:905-11.

2. Marinho LA, Rettori O, Vieira-Matos AN. Body weight loss as an indicator of breast cancer recurrence. Acta Oncol. 2001;40: 832-7.

3. Tsugane S, Sasaki S, Tsubono Y. Under- and overweight impact on mortality among middle-aged Japanese men and women: a 10-y follow-up of JPHC study cohort I. Int J Obes Relat Metab Disord. 2002;26:529-37.

4. Bae JM, Park JW, Yang HK, Kim JP. Nutritional status of gastric cancer patients after total gastrectomy. World J Surg. 1998;22: 254-60.

5. Friess H, Bohm J, Muller MW, et al. Maldigestion after total gastrectomy is associated with pancreatic insufficiency. Am $\mathbf{J}$ Gastroenterol. 1996;91:341-7.

6. Melissas J, Kampitakis E, Schoretsanitis G, et al. Does reduction in gastric acid secretion in bariatric surgery increase diet-induced thermogenesis? Obes Surg. 2002;12:236-40.

7. Adachi S, Takeda T, Fukao K. Evaluation of esophageal bile reflux after total gastrectomy by gastrointestinal and hepatobiliary dual scintigraphy. Surg Today. 1999;29:301-6.

8. Armbrecht U, Lundell L, Stockbruegger RW. Nutrient malassimilation after total gastrectomy and possible intervention. Digestion. 1987;37(Suppl 1):56-60.

9. Iesato $\mathrm{H}$, Ohya $\mathrm{T}$, Ohwada $\mathrm{S}$, et al. Jejunal pouch interposition with an antiperistaltic conduit as a pyloric ring substitute after standard distal gastrectomy: a comparison with the use of an isoperistaltic conduit. Hepatogastroenterology. 2000;47:756-60.

10. Bergh C, Sjostedt S, Hellers G, et al. Meal size, satiety and cholecystokinin in gastrectomized humans. Physiol Behav. 2003;78:143-7.

11. Braga M, Zuliani W, Foppa L, et al. Food intake and nutritional status after total gastrectomy: results of a nutritional follow-up. Br J Surg. 1988;75:477-80.

12. Fein M, Fuchs KH, Thalheimer A, et al. Long-term benefits of Roux-en-Y pouch reconstruction after total gastrectomy: a randomized trial. Ann Surg. 2008;247:759-65.

13. Liedman B. Symptoms after total gastrectomy on food intake, body composition, bone metabolism, and quality of life in gastric cancer patients-is reconstruction with a reservoir worthwhile? Nutrition. 1999;15:677-82.

14. Kojima M, Hosoda H, Date Y, et al. Ghrelin is a growth-hormone-releasing acylated peptide from stomach. Nature. 1999; 402:656-60.
15. Date Y, Kojima M, Hosoda H, et al. Ghrelin, a novel growth hormone-releasing acylated peptide, is synthesized in a distinct endocrine cell type in the gastrointestinal tracts of rats and humans. Endocrinology. 2000;141:4255-61.

16. Leite-Moreira AF, Soares JB. Physiological, pathological and potential therapeutic roles of ghrelin. Drug Discov Today. 2007;12:276-88.

17. Shintani M, Ogawa Y, Ebihara K, et al. Ghrelin, an endogenous growth hormone secretagogue, is a novel orexigenic peptide that antagonizes leptin action through the activation of hypothalamic neuropeptide Y/Y1 receptor pathway. Diabetes. 2001;50: 227-32.

18. Masuda Y, Tanaka T, Inomata N, et al. Ghrelin stimulates gastric acid secretion and motility in rats. Biochem Biophys Res Commun. 2000;276:905-8.

19. Davies JS, Kotokorpi P, Eccles SR, et al. Ghrelin induces abdominal obesity via GHS-R-dependent lipid retention. Mol Endocrinol. 2009;23:914-24.

20. Wu R, Dong W, Zhou M, et al. Ghrelin attenuates sepsis-induced acute lung injury and mortality in rats. Am J Respir Crit Care Med. 2007;176:805-13.

21. Yang J, Brown MS, Liang G, et al. Identification of the acyltransferase that octanoylates ghrelin, an appetite-stimulating peptide hormone. Cell. 2008;132:387-96.

22. Gutierrez JA, Solenberg PJ, Perkins DR, et al. Ghrelin octanoylation mediated by an orphan lipid transferase. Proc Natl Acad Sci USA. 2008;105:6320-5.

23. Hosoda H, Kojima M, Matsuo H, Kangawa K. Ghrelin and desacyl ghrelin: two major forms of rat ghrelin peptide in gastrointestinal tissue. Biochem Biophys Res Commun. 2000;279: 909-13.

24. Neary NM, Small CJ, Wren AM, et al. Ghrelin increases energy intake in cancer patients with impaired appetite: acute, randomized, placebo-controlled trial. J Clin Endocrinol Metab. 2004;89:2832-6.

25. Wren AM, Seal LJ, Cohen MA, et al. Ghrelin enhances appetite and increases food intake in humans. J Clin Endocrinol Metab. 2001;86:5992.

26. Nagaya N, Moriya J, Yasumura Y, et al. Effects of ghrelin administration on left ventricular function, exercise capacity, and muscle wasting in patients with chronic heart failure. Circulation. 2004;110:3674-9.

27. Nagaya N, Itoh T, Murakami S, et al. Treatment of cachexia with ghrelin in patients with COPD. Chest. 2005;128:1187-93.

28. Strasser F, Lutz TA, Maeder MT, et al. Safety, tolerability and pharmacokinetics of intravenous ghrelin for cancer-related anorexia/cachexia: a randomised, placebo-controlled, doubleblind, double-crossover study. Br J Cancer. 2008;98:300-8.

29. Hiura Y, Takiguchi S, Yamamoto K, et al. Effects of ghrelin administration during chemotherapy with advanced esophageal cancer patients: a prospective, randomized, placebo-controlled phase 2 study. Cancer. 2012;118:4785-94.

30. Karamanakos SN, Vagenas K, Kalfarentzos F, Alexandrides TK. Weight loss, appetite suppression, and changes in fasting and postprandial ghrelin and peptide-YY levels after Roux-en-Y gastric bypass and sleeve gastrectomy: a prospective, double blind study. Ann Surg. 2008;247:401-7.

31. Jeon TY, Lee S, Kim HH, et al. Long-term changes in gut hormones, appetite and food intake 1 year after subtotal gastrectomy with normal body weight. Eur J Clin Nutr. 2010;64:826-31.

32. Jeon TY, Lee S, Kim HH, et al. Changes in plasma ghrelin concentration immediately after gastrectomy in patients with early gastric cancer. J Clin Endocrinol Metab. 2004;89:5392-6.

33. Kamiji MM, Troncon LE, Suen VM, de Oliveira RB. Gastrointestinal transit, appetite, and energy balance in gastrectomized patients. Am J Clin Nutr. 2009;89:231-9. 
34. Kim S, Lee JH, Heo JS, et al. Serum obestatin/ghrelin ratio is altered in patients after distal gastrectomy. Dig Surg. 2009;26: $143-8$.

35. Takachi K, Doki Y, Ishikawa O, et al. Postoperative ghrelin levels and delayed recovery from body weight loss after distal or total gastrectomy. J Surg Res. 2006;130:1-7.

36. Wang HT, Lu QC, Wang Q, et al. Role of the duodenum in regulation of plasma ghrelin levels and body mass index after subtotal gastrectomy. World J Gastroenterol. 2008;14:2425-9.

37. Zub-Pokrowiecka A, Rembiasz K, Konturek PC, et al. Ghrelin and gastrin in advanced gastric cancer before and after gastrectomy. World J Gastroenterol. 2011;17:449-58.

38. Langer FB, Reza Hoda MA, Bohdjalian A, et al. Sleeve gastrectomy and gastric banding: effects on plasma ghrelin levels. Obes Surg. 2005;15:1024-9.

39. Teive MB, Russi RF, Vieira DS, et al. Quantitative immunohistochemical analysis of duodenal ghrelin cells after sleeve gastrectomy in Wistar rats. Acta Cir Bras. 2012;27:595-9.

40. Hosoda H, Kangawa K. The autonomic nervous system regulates gastric ghrelin secretion in rats. Regul Pept. 2008;146:12-8.

41. Doki Y, Takachi K, Ishikawa O, et al. Ghrelin reduction after esophageal substitution and its correlation to postoperative body weight loss in esophageal cancer patients. Surgery. 2006;139: 797-805.

42. Yamamoto K, Takiguchi S, Miyata $\mathrm{H}$, et al. Reduced plasma ghrelin levels on day 1 after esophagectomy: a new predictor of prolonged systemic inflammatory response syndrome. Surg Today. 2013;43:48-54.

43. Pekic S, Pesko P, Djurovic M, et al. Plasma ghrelin levels of gastrectomized and vagotomized patients are not affected by glucose administration. Clin Endocrinol (Oxf). 2006;64:684-8.

44. Takeno R, Okimura $Y$, Iguchi $G$, et al. Intravenous administration of ghrelin stimulates growth hormone secretion in vagotomized patients as well as normal subjects. Eur J Endocrinol. 2004;151: 447-50.

45. le Roux CW, Neary NM, Halsey TJ, et al. Ghrelin does not stimulate food intake in patients with surgical procedures involving vagotomy. J Clin Endocrinol Metab. 2005;90:4521-4.

46. Arnold M, Mura A, Langhans W, Geary N. Gut vagal afferents are not necessary for the eating-stimulatory effect of intraperitoneally injected ghrelin in the rat. J Neurosci. 2006;26:11052-60.

47. Adachi S, Takiguchi S, Okada K, et al. Effects of ghrelin administration after total gastrectomy: a prospective, randomized, placebo-controlled phase II study. Gastroenterology. 2010;138: 1312-20.

48. Yamamoto K, Takiguchi S, Miyata H, et al. Randomized phase II study of clinical effects of ghrelin after esophagectomy with gastric tube reconstruction. Surgery. 2010;148:31-8.

49. Takiguchi S, Hiura $\mathrm{Y}$, Takahashi $\mathrm{T}$, et al. Effect of rikkunshito, a Japanese herbal medicine, on gastrointestinal symptoms and ghrelin levels in gastric cancer patients after gastrectomy. Gastric Cancer. 2012;. doi:10.1007/s10120-012-0164-3 (Epub 2012/08/ 17 PubMed PMID: 22895614).

50. Yeh AH, Jeffery PL, Duncan RP, et al. Ghrelin and a novel preproghrelin isoform are highly expressed in prostate cancer and ghrelin activates mitogen-activated protein kinase in prostate cancer. Clin Cancer Res. 2005;11:8295-303.
51. Duxbury MS, Waseem T, Ito H, et al. Ghrelin promotes pancreatic adenocarcinoma cellular proliferation and invasiveness. Biochem Biophys Res Commun. 2003;309:464-8.

52. Cassoni P, Allia E, Marrocco T, et al. Ghrelin and cortistatin in lung cancer: expression of peptides and related receptors in human primary tumors and in vitro effect on the H345 small cell carcinoma cell line. J Endocrinol Invest. 2006;29:781-90.

53. Jeffery PL, Murray RE, Yeh AH, et al. Expression and function of the ghrelin axis, including a novel preproghrelin isoform, in human breast cancer tissues and cell lines. Endocr Relat Cancer. 2005; $12: 839-50$.

54. Mottershead M, Karteris E, Barclay JY, et al. Immunohistochemical and quantitative mRNA assessment of ghrelin expression in gastric and oesophageal adenocarcinoma. J Clin Pathol. 2007;60:405-9.

55. Garin MC, Burns CM, Kaul S, Cappola AR. The human experience with ghrelin administration. J Clin Endocrinol Metab. 2013;98:1826-37.

56. Murphy G, Kamangar F, Dawsey SM, et al. The relationship between serum ghrelin and the risk of gastric and esophagogastric junctional adenocarcinomas. J Natl Cancer Inst. 2011;103: 1123-9.

57. Murphy G, Kamangar F, Albanes D, et al. Serum ghrelin is inversely associated with risk of subsequent oesophageal squamous cell carcinoma. Gut. 2012;61:1533-7.

58. Chen HY, Trumbauer ME, Chen AS, Weingarth DT, Adams JR, Frazier EG, et al. Orexigenic action of peripheral ghrelin is mediated by neuropeptide $\mathrm{Y}$ and agouti-related protein. Endocrinology. 2004;145:2607-12.

59. Kamegai J, Tamura H, Shimizu T, Ishii S, Sugihara H, Wakabayashi I. Chronic central infusion of ghrelin increases hypothalamic neuropeptide $\mathrm{Y}$ and Agouti-related protein mRNA levels and body weight in rats. Diabetes. 2001;50:2438-43.

60. Gibney J, Healy ML, Sonksen PH. The growth hormone/insulinlike growth factor-I axis in exercise and sport. Endocr Rev. 2007;28:603-24.

61. Nass R, Pezzoli SS, Oliveri MC, Patrie JT, Harrell FE Jr, Clasey JL, et al. Effects of an oral ghrelin mimetic on body composition and clinical outcomes in healthy older adults: a randomized trial. Ann Intern Med. 2008;149:601-11.

62. Velloso CP. Regulation of muscle mass by growth hormone and IGF-I. Br J Pharmacol. 2008;154:557-68.

63. Li WG, Gavrila D, Liu X, Wang L, Gunnlaugsson S, Stoll LL, et al. Ghrelin inhibits proinflammatory responses and nuclear factor-kappaB activation in human endothelial cells. Circulation. 2004;109:2221-6.

64. Waseem T, Duxbury M, Ito H, Ashley SW, Robinson MK. Exogenous ghrelin modulates release of pro-inflammatory and anti-inflammatory cytokines in LPS-stimulated macrophages through distinct signaling pathways. Surgery. 2008;143:334-42.

65. Delhanty PJ, van der Lely AJ. Ghrelin and glucose homeostasis. Peptides. 2011;32:2309-18.

66. van der Lely AJ, Tschop M, Heiman ML, Ghigo E. Biological, physiological, pathophysiological, and pharmacological aspects of ghrelin. Endocr Rev. 2004;25:426-57. 